\title{
A conglutination test for rapid detection of antibodies against Babesia bigemina ${ }^{1}$
}

\author{
Claudio R. Madruga², Raul H. Kessler², Maria A. M. Schenk² and Midori Miguita²
}

\begin{abstract}
Madruga C.R., Kessler R.H., Schenk M.A.M. \& Miguita M. 2000. A conglutination test for a rapid detection of antibodies against Babesia bigemina. Pesquisa Veterinária Brasileira 20(4):161-166. Embrapa Gado de Corte, Rodovia BR 262, Km 4, Cx. Postal 154, Campo Grande, MS 79002-970, Brazil.

A rapid conglutination test (RCT) with performance comparable to the indirect fluorescent antibody technique (IFAT) was developed to detect antibodies against Babesia bigemina (B. bigemina-RCT). The B. bigemina-RCT is a sensitive, specific, economical, and rapidly performed serological test suitable for field application or minimally equipped laboratories. This test had a sensitivity of $90.9 \%$ and specificity of $97.6 \%$ compared to IFAT, which showed for the same parameters respectively, $98.3 \%$ and $99.7 \%$ The early detection of anti- B. bigemina immunoglobulins by RCT in experimental infections was nearly parallel to that of IFAT. Cross reactions were observed with sera from calves experimentally infected with Babesia bovis $(1.8 \%$ and with Anaplasma marginale $(1.2 \%$. RCT antigen prepared with non parasitized erythrocytes (negative antigen) showed 1.5\% 3.5\% and 2.2\% of positive reactions with sera from animals experimentally infected with B. bigemina, B. bovis and A. marginale. However, none of the sera from animals of endemic areas for babesia infection resulted in positive reactions with the negative antigen. Considering these results and shelf life over six months, the B. bigemina-RCT could be used for epidemiological surveys and evaluation of control measures against this species of Babesia.
\end{abstract}

INDEX TERMS: Babesia bigemina, antibodies, serological test, conglutination.

\begin{abstract}
RESUM 0.- [Teste de conglutinação rápida para detecção de anticorpos contra Babesia bigemina.] Um teste rápido de conglutinação (TCR) com desempenho comparável a imunofluorencência indireta (IFI) foi desenvolvido para detectar anticorpos contra Babesia bigemina. O TCR-B. bigemina é um teste sorológico sensível, econômico e executável rapidamente; apropriado para condições de campo ou laboratórios com estrutura mínima. Este teste tem uma sensibilidade de $90,9 \%$ e especificidade de $97,6 \%$ enquanto que a IFI apresentou para os mesmos parâmetros, respectivamente, $98,3 \%$ e 99,7\% Nas infecções experimentais a detecção de imunoglobulinas anti-B. bigemina pelo TCR foi aproximadamente a mesma da IFI. As reações cruzadas verificadas nos soros de bezerros experimentalmente infectados com Babesia bovis e Anaplasma marginale foram $1,8 \%$ e $1,2 \%$ respectivamente. 0
\end{abstract}

\footnotetext{
${ }^{1}$ Accepted for publication on June 30, 2000.

${ }^{3}$ Embrapa Gado de Corte, Rodovia BR 262 Km 4, Cx.Postal 154, Campo Grande, MS 79002-970, Brazil.
}

antígeno preparado com eritrócitos não parasitados (antígeno negativo) apresentou $1,5 \%$ 3,5\% e 2,2\%de reações positivas com os soros de animais infectados com B. bigemina, B. bovis e A. marginale. Entretanto, nenhum dos soros dos animais de áreas endêmicas para infecção de babésia resultaram em reações positivas com o antígeno negativo. Considerando estes resultados e o período de viabilidade do antígeno de TCR, acima de seis meses, possibilita o TCR-B. bigemina ser utilizado em levantamentos epidemiológicos e na avaliação das medidas de controle contra esta espécie de Babesia.

TERMOS DE INDEXAÇÃO: Babesia bigemina, anticorpos, teste sorológico, conglutinação.

\section{INTRODUCTION}

Babesia bigemina together with Babesia bovis cause important economic losses to cattle production in tropical and subtropical areas of the world (McCosker 1981). Babesiosis outbreaks occur in these areas due to importation of cattle from diseasefree to endemic or in a naturally or artificially unstable area. The latter would occur as consequence of intensive tick 
control measures and the former in regions near the parallel $32^{\circ}$ or in dry regions of northeastern Brazil. In these situations, epidemiological studies and the application and evaluation of control measures are needed.

Serological tests are very important in accomplishing these tasks. Over the last few decades, various serological techniques have been developed to increase sensitivity and specificity (Wright 1990). Highly purified antigens have recently been obtained through molecular biological methods. Subunit antigens with defined specificity have been used in enzymelinked immunosorbent assay (ELISA) (Goff et al. 1989, Böse et al. 1995), but in spite of these improvements, the sensitivity obtained was not superior to that of the indirect fluorescent antibody technique (IFAT). Other desirable test characteristics besides specificity and sensitivity would include simplicity, economy and rapid results such that the assay could be used in minimally equipped laboratories or under field conditions.

Agglutination tests meet most of these requirements, however, usually agglutination test sensitivity is lower than that of other serological tests. The introduction of conglutinin, considerably increased the sensitivity of the card agglutination test for detection of antibodies against Anaplasma marginale (Amerault et al. 1972, Rose et al. 1974). The present paper describes the development and evaluation of a rapid conglutination test (RCT) for the detection of antibodies against $B$. bigemina.

\section{MATERIALS AND METHODS}

Parasitized erythrocytes. Pure B. bigemina from Mato Grosso do Sul State, Brazil isolate (GC-5118-3) was used as inoculum to obtain parasitized erythrocytes. Splenectomized Nelore (Bos indicus) calves which were born and raised in tick free isolation facilities of National Center of Beef Cattle Research (Embrapa Gado de Corte) were experimentally infected. Sub-inoculations were done until a parasitemia of 5\%for IFAT and 30\%or more for RCT were achieved.

Antigen preparation for B. bigemina-RCT and negative-RCT. The antigen preparation was done with modifications of the techniques described by Amerault \& Roby (1968) and Todorovic \& Kuttler (1974). Blood from calves with high parasitemia was collected in flasks with sodium citrate as anticoagulant. After washing three times with saline phosphate buffer $\left(10 \mathrm{mM} \mathrm{Na}_{2} \mathrm{HPO}_{4} 2 \mathrm{H}_{2} \mathrm{O}, 6.4 \mathrm{mM}\right.$ $\mathrm{NaH}_{2} \mathrm{PO}_{4} \cdot \mathrm{H}_{2} \mathrm{O}, 100 \mathrm{mM} \mathrm{NaCl}$ ), $\mathrm{pH} 7.2$, (PBS), the blood sediment was homogenized in equal volume of distilled water and frozen at $80^{\circ} \mathrm{C}$. For antigen preparation, blood was thawed at room temperature and centrifuged at $10,000 \times \mathrm{g}$ for 30 minutes. The supernatant was discarded and the sediment was washed three times with PBS containing $0.1 \mathrm{mM}$ calcium and $0.6 \mathrm{mM}$ magnesium and penicillin-streptomycin (1 $\mathrm{Ul} / \mathrm{ml}$ penicillin, $1 \mathrm{mg} / \mathrm{ml}$ streptomycin) (PBMA). Between washings the parasites and erythrocyte stroma were homogenized in a ten tissue grinder and sonicated at 50 watts, low intensity for 30 seconds. The pellet after the last wash was resuspended in PBMA and frozen by 24 hours at $-80^{\circ} \mathrm{C}$. The antigenic material was than thawed in a water bath at $37^{\circ} \mathrm{C}$ then sonicated and centrifuged as described above. Walpoles buffer $\left(0.1 \mathrm{~N} \mathrm{C}_{2} \mathrm{H}_{4} \mathrm{O}_{2}\right.$, $100 \mathrm{mM} \mathrm{C} \mathrm{H}_{3} \mathrm{Na}, 100 \mathrm{mM} \mathrm{C}_{8} \mathrm{H}_{8} \mathrm{O}_{3}$ ) was employed in two additional washes at $10,000 \times \mathrm{g}$ for 30 minutes. After these procedures fast green stain was added in the proportion of 1:20. The dye excess was removed by descarding the supernatant after centrifugation at $10,000 \times \mathrm{g}$ for 30 minutes. The pellet was resuspended in Walpoles buffer. The negative-RCT was done by the same procedure utilizing non-parasitized erythrocytes. The final concentration of the unsoluble material was of $4-5 \%$ determined in a microhematocrit tube.

Bovine serum factor (BSF). The BSF source was a pool of bovine sera from B. indicus, six to nine-month-old Nelore breed calves, raised in the isolation area of Embrapa Gado de Corte. All animals were clinically healthy and monitored monthly by IFAT from birth to date of BSF collection to ensure that the sera was negative for antibodies against Babesia sp. and Anaplasma sp. The choice of a B. indicus breed as BSF source was based on data obtained by Kakoma \& Kinyanjui (1974).

Standardization and execution of the B. bigemina-RCT. The RCT standardization was done with 25 sera from cattle known as infected with B. bigemina and positive in the IFAT and 25 sera from uninfected cattle. The RCT was performed as described for the Anaplasma card test (Amerault et al. 1972). Briefly, $15 \mathrm{mml}$ of test serum, $30 \mathrm{mml}$ of BSF and $15 \mathrm{mml}$ of antigen were placed on a glass plate. All three components were mixed and agitated on a shaker for eight minutes. The optimal antigen concentration was determined considering time of reaction and agglutination intensity. The reading criteria was the following: negative (-) without clumps; weak positive (+) small amount of clumps; positive $(++)$ regular amount of clumps; strong positive $(+++)$ intense amount of clumps; very strong $(++++)$ very intense reaction with clot formation.

Indirect fluorescent antibody technique (IFAT). The IFAT was performed basically according Goff et al. (1982). The following modifications were included: (a) infected blood was collected before antibody was detectable by IFAT, and (b) the antigen slides were stored at $-80^{\circ} \mathrm{C}$ without acetone fixation.

Sera analysis of animals infected with B. bigemina. Sixty sera from calves infected experimentally with $B$. bigemina stabilate (GC5118-3) for antigen production or heifers immunized with B. bigemina attenuated vaccine were analyzed by RCT and IFAT. All animals were B. bigemina positive in thin blood smears stained with May-Grünwald Giemsa.

Antibody detection post-infection with B. bigemina. Serum samples from five calves inoculated with $50 \mathrm{ml}$ of fresh blood of a calf with $0.1 \%$ B. bigemina parasitemia were monitored daily until the tenth day post-infection (DPI) by RCT and IFAT. After, the serum sampling was done at 45, 60, 90 and $145 \mathrm{DPI}$. The parasitemia was detected using May-Grünwald Giemsa staining.

Detection of antibodies in cattle inoculated with different number of B. bigemina merozoites. To analyse the relationship between inoculum and antibody detection by RCT and IFAT, 16 calves were divided in four groups. The inocula were the following: group A, $10^{7}$; group B, $5 \times 10^{6}$; group C, $10^{6}$ and group $D$, control without inoculum. The serological analysis was done at 14 and $28 \mathrm{DPI}$.

Sera analysis from non-infected cattle. Sera of 210 Holstein heifers from United States (Illinois State), five Blonde Aquitaine heifers from France, and 80 cattle from South Brazil, were used to evaluate the RCT specificity. These areas are free of Boophilus microplus and Boophilus annulatus ticks and all sera were negative for antibodies against Babesia sp. in the IFAT.

Evaluation of crossed reactions. One hundred and fourteen serum samples from cattle infected with B. bovis and 82 from cattle infected with $A$. marginale were analyzed by the $B$. bigemina-RCT. 
Sera analysis of cattle infected experimentally and from endemic areas with RCT negative antigen. The evaluation of the negative antigen was performed with serum samples from 66, 57 and 89 animals experimentally infected, respectively, with B. bigemina, B. bovis and A. marginale. Additionally, 395 sera from different geographical Babesia sp. endemic areas of Brazil which had shown 94.6\% of positive in the RCT-B. bigemina were also evaluated with the negative antigen.

Antigen stability. A batch of RCT-B.bigemina antigen was evaluated for reproducibility of results with ten positive sera collected from cattle vaccinated with attenuated B. bigemina and ten negative sera from calves raised in the isolation building at Embrapa Gado de Corte. The tests were performed monthly during 270 days. All these sera were previously analyzed by RCT-B. bigemina, and aliquots of each serum was separated in $100 \mathrm{mml}$ volume and stored at $-20^{\circ} \mathrm{C}$. Each aliquot was used only once in the RCT-B. bigemina antigen stability evaluation.

Statistical analysis. In the statistical comparison between RCT and IFAT was employed correlation analysis through proceeding correlation of the Statistical System Analysis (SAS 1982).

\section{RESULTS}

The antigen with $5 \%$ of solid material displayed reaction with all 25 positive sera $(10+, 7++, 6+++, 2++++)$ and no reaction was verified with sera from uninfected cattle. Fifty
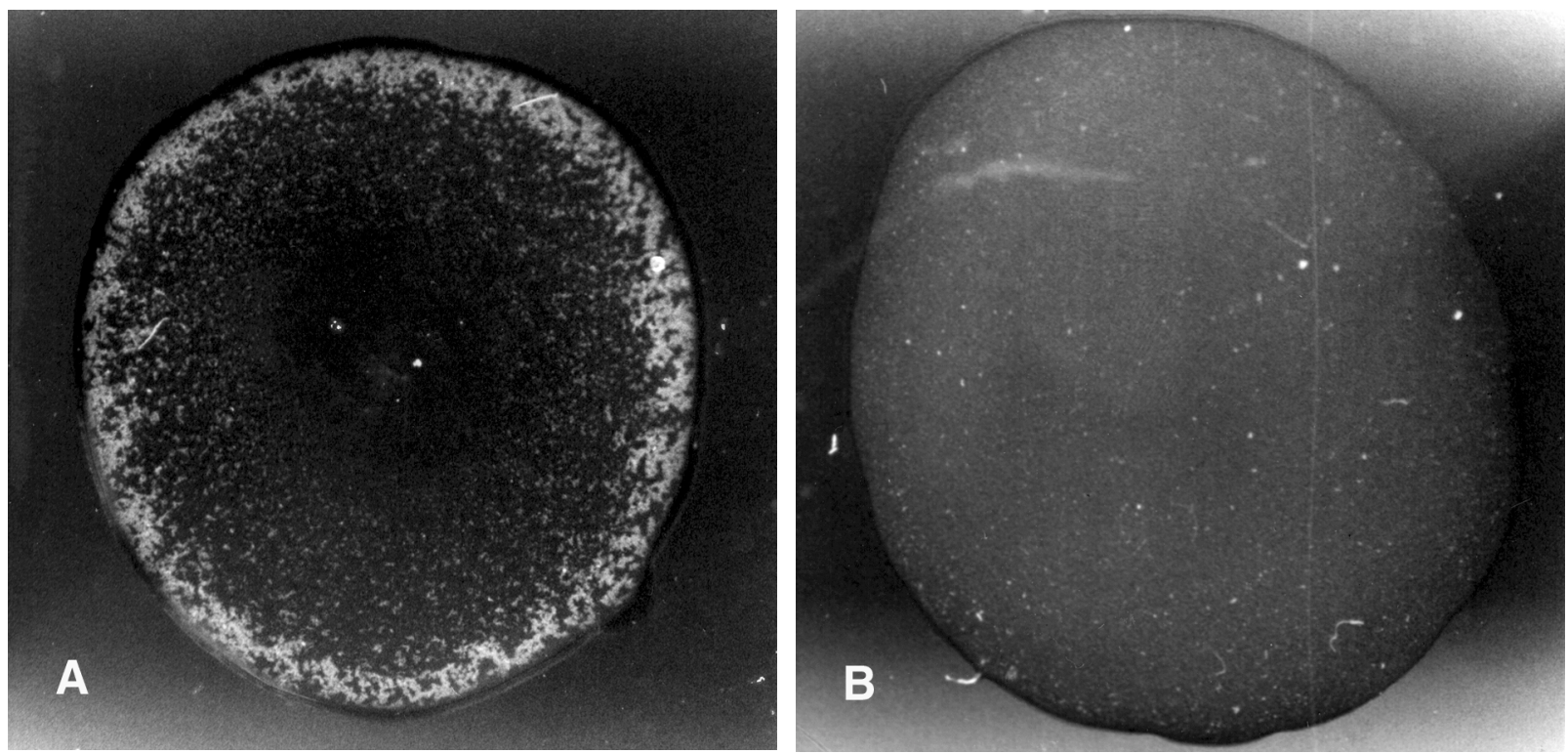

Fig. 1. Babesia bigemina-RCT pattern of agglutination: (A) Positive reaction, (B) Negative reaction.

Table 1. Antibody detection in calf by IFAT and RCT after experimental inoculation of Babesia bigemina

\begin{tabular}{|c|c|c|c|c|c|c|c|c|c|c|c|c|c|c|c|}
\hline \multirow{3}{*}{$\begin{array}{c}\text { Days } \\
\text { post-infection }\end{array}$} & \multicolumn{15}{|c|}{ Calf number } \\
\hline & \multicolumn{3}{|c|}{1} & \multicolumn{3}{|c|}{2} & \multicolumn{3}{|c|}{3} & \multicolumn{3}{|c|}{4} & \multicolumn{3}{|c|}{5} \\
\hline & pa & $\mathrm{RCT}^{\mathrm{b}}$ & IFATC & $P$ & RCT & IFAT & $P$ & RCT & IFAT & P & RCT & IFAT & P & RCT & IFAT \\
\hline 1 & 0 & - & 0 & 0 & - & 0 & 0 & - & 0 & 0 & - & 0 & 0 & - & 0 \\
\hline 2 & 0 & - & 0 & 0 & - & 0 & 0 & - & 0 & 0 & - & 0 & 0 & - & 0 \\
\hline 3 & 0 & - & 0 & 0 & - & 0 & 0 & - & 0 & 0 & - & 0 & 0 & - & 0 \\
\hline 4 & 0 & - & 0 & 0.01 & - & 0 & 0 & - & 0 & 0 & - & 0 & 0 & - & 0 \\
\hline 5 & 0 & - & 0 & 0.1 & - & 0 & 0 & - & 0 & 0.09 & + & $1: 40$ & 0 & - & 0 \\
\hline 6 & 0.01 & - & $1: 80$ & 0.7 & - & $1: 40$ & 0.02 & - & $1: 40$ & 0 & + & $1: 40$ & 0 & - & 0 \\
\hline 7 & 0.01 & + & $1: 80$ & 0.5 & + & $1: 80$ & 0 & + & $1: 80$ & 0 & + & $1: 80$ & 0 & - & 0 \\
\hline 8 & 0 & + & $1: 80$ & 0.3 & + & $1: 80$ & 0 & ++ & $1: 80$ & 0 & + & $1: 80$ & 0 & - & 0 \\
\hline 9 & 0 & + & $1: 80$ & 0.4 & + & $1: 80$ & 0 & ++ & $1: 80$ & 0 & + & $1: 80$ & 0 & - & 0 \\
\hline 10 & 0 & ++ & $1: 80$ & 0.1 & ++ & $1: 80$ & 0 & ++ & $1: 80$ & 0 & + & $1: 80$ & 0.8 & ++ & $1: 80$ \\
\hline 45 & 1.6 & ++ & $1: 80$ & 0 & +++ & $1: 80$ & 1.3 & + & $1: 80$ & 0 & + & $1: 80$ & 0 & ++ & $1: 80$ \\
\hline 60 & 0.9 & ++ & $1: 80$ & 0 & +++ & $1: 80$ & 0 & + & $1: 80$ & 0 & ++ & $1: 80$ & 0 & ++ & $1: 80$ \\
\hline 90 & 0 & ++ & $1: 80$ & 0 & +++ & $1: 80$ & 0 & ++ & 1.80 & 0 & ++ & $1: 80$ & 0 & +++ & $1: 80$ \\
\hline 145 & 0 & ++ & $1: 80$ & 0 & +++ & $1: 80$ & 0 & +++ & $1: 80$ & 0 & ++ & $1: 80$ & 0 & +++ & $1: 80$ \\
\hline
\end{tabular}

a $P=$ parasitemia

${ }^{\mathrm{b}}$ Qualitative result $=$ agglutination degree in the RCT.

c Title in the IFAT. 
Table 2. Sensitivity of the RCT and IFAT in the detection of antibodies in cattle inoculated with Babesia bigemina organisms

\begin{tabular}{|c|c|c|c|c|c|c|c|c|c|c|c|c|c|}
\hline \multirow{3}{*}{$\begin{array}{c}\text { Time } \\
\text { post- } \\
\text { infection } \\
\text { (days) }\end{array}$} & \multirow{3}{*}{$\begin{array}{l}\text { Serological } \\
\text { test }\end{array}$} & \multicolumn{12}{|c|}{ Experimental groups } \\
\hline & & \multicolumn{4}{|c|}{$A^{a}$} & \multicolumn{4}{|c|}{$\mathrm{B}^{\mathrm{b}}$} & \multicolumn{4}{|c|}{$\mathrm{C}^{\mathrm{C}}$} \\
\hline & & 1 & 2 & 3 & 4 & 1 & 2 & 3 & 4 & 1 & 2 & 3 & 4 \\
\hline \multirow[t]{2}{*}{0} & IFAT ${ }^{d}$ & 0 & 0 & 0 & 0 & 0 & 0 & 0 & 0 & 0 & 0 & 0 & 0 \\
\hline & $\mathrm{RCT}$ e & - & - & - & - & - & - & - & - & - & - & - & - \\
\hline \multirow[t]{2}{*}{14} & IFAT & 1: 80 & $1: 80$ & 0 & $1: 80$ & $1: 40$ & 0 & 0 & 0 & 0 & 0 & 0 & 0 \\
\hline & $\mathrm{RCT}$ & - & + & - & - & ++ & - & - & - & - & +++ & - & - \\
\hline \multirow[t]{2}{*}{28} & IFAT & $1: 80$ & $1: 80$ & $1: 80$ & $1: 80$ & $1: 80$ & 0 & 0 & $1: 80$ & 0 & 0 & 0 & 0 \\
\hline & RCT & +++ & +++ & ++ & +++ & ++ & - & - & - & - & ++ & - & - \\
\hline \multicolumn{14}{|c|}{$\begin{array}{l}\text { aGroup A: inoculated with } 10^{7} \text { organisms, } \\
\text { b Group B: inoculated with } 5 \times 10^{6} \text { organisms, } \\
\text { c Group C: inoculated with } 10^{6} \text { organisms, } \\
\text { Group D: all animals negative in both serological } \\
\text { d Title in the IFAT. }\end{array}$} \\
\hline
\end{tabular}

Table 3. Specificity, cross reactions of Babesia bigemina-RCT and cross reactions with RCT-negative antigen

\begin{tabular}{|c|c|c|c|c|c|c|c|}
\hline \multirow{3}{*}{$\begin{array}{c}\text { Positive } \\
\text { sera }\end{array}$} & \multicolumn{7}{|c|}{ RCT Antigen } \\
\hline & \multicolumn{4}{|c|}{ B. bigemina } & \multicolumn{3}{|c|}{ Negative } \\
\hline & $\begin{array}{l}\text { Negative } \\
\text { number }\end{array}$ & $\begin{array}{l}\text { Positive } \\
\text { number }\end{array}$ & Cross & $\begin{array}{l}\text { reaction } \\
1 \%\end{array}$ & $\begin{array}{l}\text { Negative } \\
\text { number }\end{array}$ & $\begin{array}{l}\text { Positive } \\
\text { number }\end{array}$ & $\begin{array}{c}\text { Cross reaction } \\
(\%)\end{array}$ \\
\hline B. $b$ & 112 & 2 & & 1.8 & 55 & 2 & 3.5 \\
\hline A. marginale & 81 & 1 & & 1.2 & 87 & 2 & 2.2 \\
\hline B. bigemina & 0 & 66 & & - & 65 & 1 & 1.5 \\
\hline
\end{tabular}

Table 4. Analysis of the RCT-Babesia bigemina antigen longevity with standard positive calf sera to this Babesia species

\begin{tabular}{|c|c|c|c|c|c|c|c|c|c|c|}
\hline \multirow{2}{*}{$\begin{array}{l}\text { Animal } \\
\text { number }\end{array}$} & \multicolumn{10}{|c|}{ Time of post-antigen preparation (days) } \\
\hline & 0 & 30 & 60 & 90 & 120 & 150 & 180 & 210 & 240 & 270 \\
\hline 1 & ++ & ++ & ++ & ++ & +++ & +++ & +++ & ++ & ++ & ++ \\
\hline 2 & ++ & ++ & ++ & ++ & ++ & ++ & ++ & +++ & ++ & - \\
\hline 3 & ++ & ++ & ++ & +++ & +++ & +++ & +++ & ++ & ++ & - \\
\hline 4 & ++ & +++ & +++ & +++ & ++ & ++ & ++ & ++ & ++ & - \\
\hline 5 & ++ & +++ & +++ & +++ & +++ & +++ & ++ & ++ & ++ & - \\
\hline 6 & ++ & +++ & +++ & +++ & ++ & ++ & ++ & +++ & +++ & + \\
\hline 7 & ++ & ++ & ++ & +++ & +++ & +++ & +++ & +++ & ++ & + \\
\hline 8 & ++ & +++ & +++ & +++ & +++ & +++ & +++ & ++ & ++ & ++ \\
\hline 9 & ++ & +++ & +++ & ++ & ++ & ++ & ++ & ++ & ++ & - \\
\hline 10 & +++ & +++ & +++ & +++ & +++ & +++ & +++ & +++ & +++ & ++ \\
\hline
\end{tabular}

Data not shown: All ten negative calves sera remained did not reacted with the antigen during the experimental time.

nine and 54 out of 60 sera of B. bigemina infected animals were positive in IFAT, and RCT, respectively. Therefore the sensitivity of the first serological test was $98.3 \%$ and the second $90.9 \%$ The patterns of positive and negative reactions can be seen in Fig.1.
All calves experimentally infected displayed parasitemia varying between fourth and tenth DPI (Table 1). Antibodies against $B$. bigemina raised to detectable level in IFAT, on the fifth DPI in one calf, on the sixth DPI in three of them and the remaining one at tenth DPI (Table 1 ). The RCT detected 
antibodies in three calves one day later of the IFAT and the other two at same time (Table 1). The average of first detection of antibodies was 6.6 DPI for IFAT and 7.2 DPI for RCT. After the detection of specific immunoglobulins against B. bigemina both serological tests were positive until the end of the experiment.

The animals inoculated with $10^{7} \mathrm{~B}$. bigemina organisms had antibodies detected at $14 \mathrm{DPI}$ in three calves by IFAT and one by RCT, and at $28 \mathrm{DPI}$ all calves were positive for both tests (Table 2). The inocula $5 \times 10^{6}$ and $10^{6}$ lowered number of calves positive for IFAT and RCT during the experimental time (Table 2).

The specificity found by RCT and IFAT was respectively 97.6\% and $99.7 \%$ The RCT-B.bigemina showed $1.8 \%$ and $1.2 \%$ of false positive with, respectively, B. bovis and A. marginale positive sera (Table 3). The RCT-negative antigen showed with B. bovis, A. marginale and B. bigemina positive sera 3.5\% 2.2\% and $1.5 \%$ of false-positive reactions, respectively (Table 3 ). None of the sera from endemic areas showed false-positive reaction with RCT negative antigen. The batch of RCT-B. bigemina analyzed presented reproducibility of results until 240 days after antigen preparation (Table 4).

\section{DISCUSSION}

Despite the higher percentage of positive reactions in IFAT, there was no statistical difference of sensitivity between RCT and IFAT $\left(\mathrm{P}^{33} \mathrm{O} .05\right)$ nor the specificity. The elevated sensitivity and specificity encountered in IFAT is in agreement with Ross \& Löhr (1968) who first developed this serological technique. The average of first antibody detection on RCT and IFAT in the present work was close to that which Reddy et al. (1997) found with IFAT and ELISA. At seven DPI the IFAT had detected $87.5 \%$ while the ELISA $100.0 \%$ of positive. An indirect comparison between results obtained by RCT and IFAT in this work indicated that the former probably has better performance than complement fixation test (CFT), because it detected antibodies 2.5 weeks later than IFAT (Todorovic et al. 1976). Other indirect comparison that RCT and IFAT have better sensitivity than CFT is given by Kuttler et al. (1977) where at 98 DPI $60.0 \%$ of calves inoculated with B. bigemina stabilate were negative in the CFT. In relation to the number of inoculated parasites the overall results did not show significant differences in sensitivity between RCT and IFAT.

RCT-B. bigemina cross reactions with positive sera to $B$. bovis and $A$. marginale were within acceptable levels. Additionally it was not quite distinct from a radioimmunoassay which registered $4.0 \%$ of cross reaction with B. bovis and $0.0 \%$ with A. marginale sera (Schuntner \& Wright 1989). The percentage of cross reactions may be related with the following factors: 1 ) the sera was collected during the acute and convalescent phase period of infection in which the predominant immunoglobulin isotype is IgM which has more promiscuous affinity than $\mathrm{gG}$ for the antigenic determinants due to the affinity maturation phenomena, 2) the hemolytic characteristics of the B. bigemina infection could induce antibody production against erythrocyte stroma what would be more pronounced in the acute and convalescent phase and, 3) polyclonal $B$ cell activation. Therefore, the infection phase of the B. bovis and A. marginale could be the cause of the cross reactions with $B$. bigemina antigen. This hypothesis is supported by the observation that sera from animals of enzootic areas did not show cross reactions. The overall percentage of cross reactions will not impair the use of RCT as a serological test for epidemiological studies because the specificity was above $95.0 \%$ Also the negative antigen analysis showed that the erythrocyte stroma did not interfere in the test performance, particularly when the sera were from cattle chronically infected, such as those from enzootic areas, because the percentage of false positives were lower or very close the percentage of crossed reactions or specificity of the $\mathrm{B}$. bigemina-RCT.

Babesia-infected animals possess dynamic antibody production. In the primary humoral response to Babesia, IgM and IgGI are produced which are detected by agglutination tests, CFT, IFAT and ELISA. In chronic infections the antibody concentration declines and almost exclusively the lgG isotype persists. This isotype is responsible for the persistent reactions verified in IFAT. The CFT reaction depends of the presence of complement fixing antibodies, the most important of which are of the IgM isotype. For this reason CFT is considered a good test for identification of recent infections but it fails in the detection of chronically infected animals and is thus not appropriate for prevalence studies.

The RCT being a conglutination is a reaction that occurs in cascade. First antigen-antibody reaction followed by complement fixation and at end the conglutinin binds to $\mathrm{C} 3$ component of the complement (Moreira et al. 1992). Based on this mechanism, the RCT difference from the CFT is the participation of conglutinin in the reaction. The higher sensitivity may be associated to this component in the reaction, since RCT sensitivity was greater than the CFT (Kuttler et al. 1977), and in fact it was comparable to that of the IFAT (Pf0.005).

The RCT showing a specificity of $97.6 \%$ overcame the problems of non-specific agglutination which occurred with the rapid agglutination test developed by Todorovic $\&$ Kuttler (1974). The difference in the degrees of agglutination may be influenced by temperature as in any agglutination test but this is not relevant because $\mathrm{B}$. bigemina-RCT is a qualitative serological test.

The RCT data obtained is an improvement for B. bigemina serological diagnostic since until recently the existing serological tests lacked sensitivity and specificity according Böse et al. (1995). Additionally the test is simpler and faster to perform compared to indirect haemagglutination (Goodger $\&$ Mahoney 1974), radioimmunoassay (Schuntner \& Wright 1989 ) and immunoadsorbent assays (O'Donoghue et al. 1985, Reddy et al. 1997) making it possible to employ in various regions of Brazil, where the facilities for serological diagnosis are minimal. Although the antigen average longevity was only 
six months, the results of the RCT make it applicable for epidemiological studies and evaluation of the immunization with attenuated vaccine or by sub-inoculation of cattle blood from a chronic B. bigemina carrier of the virulent organism. The variation in the degree intensity of the observed reactions with some positive sera during antigen evaluation is not clear, but could be associated with subjective reading or the influence of temperature which occur in any type of agglutination reaction. However, the degree of variation was not enough to cause problems of false positive or negative results as well as those observed with negative controls or positive sera tested.

\section{REFERENCES}

Amerault T.E. \& Roby T.O. 1968. A rapid card agglutination test for bovine anaplasmosis. J. Am. Vet. Med. Assoc. 153:1828-1834.

Amerault T.E., Rose J.E. \& Roby T.O. 1972. Modified card agglutination test for bovine anaplasmosis. Proc.76th Annual Meeting on Animal Health, $p$. 736-744.

Böse R., Jorgensen W.K., Dalgliesh R.J., Friedhoff K.T. \& Vos A.J. 1995. Current state and future trends in the diagnosis of babesiosis. Vet. Parasitol. 57:61-74.

Goodger B.V. \& Mahoney D.F. 1974. Evaluation of the parasite haemmagglutination for the diagnosis of Babesia argentina infection in catle. Aust. Vet. J. 50:246-249.

Goff W.L., Wagner G.G., Craig T.M. \& Long R.F. 1982. The bovine immune response to tick-derived Babesia bovis infection: Serological studies of isolated immunoglobulins. Vet. Parasitol. 11:109-120.

Goff W.L., Palmer G.H., M CElvain T.F. \& Davis W.C. 1989. Development of ELISA diagnostic test for Babesia infections using highly immunogenic specie specific and strain common surface glycoproteins. 8th National Veterinary Hemoparasite Disease Conference, p. 353-376.

Kakoma I. \& Kinyanjui M. 1974. Effect of breed and age on the distribution of cattle immunoconglutinin and immunoconglutinin in normal cattle. Res.Vet. Sci. 117:122-124.

Kuttler K.L., Adams L.G. \& Todorovic R.A. 1977. Comparisons of the complement fixation and indirect fluorescent antibody reactions in the detection of bovine babesiosis. Am. J. Vet. Res. 38:153-156.

McCosker P.J. 1981. The global importance of babesiosis, p.1-24. In: Ristic M. $\&$ Krier J.P. (ed.) Babesiosis. Academic Press, New York.

Moreira T., Alonso M. \& Villegas M.I. 1992. The use of sodium glutamate to improve stability of freeze dried bovine serum factor (conglutinin) used in the card test for Anaplasma marginale. Revta Salud Anim. 14:197-200.

O'Donoghue P.J., Friedhoff K.T.,Viscaino O.G. \& Weyreter H. 1985. The detection of IgM and IgG antibodies against Babesia bigemina in bovine sera using a semi- defined antigens in enzyme immunoassays. Vet. Parasitol. 18:1-12.

Reddy G.G.B., Mishra A.K., Rao J.R. \& Tewari A.K. 1997. Comparison of indirect immunofluorescence and enzyme-linked immunosorbent assay (ELISA) in detecting Babesia bigemina infection in cattle. Acta Vet. Hung. 45:67-74.

Ross J.P.J. \& Löhr K.F. 1968. Serological diagnosis of Babesia bigemina infection in cattle by indirect fluorescent antibody test. Res. Vet. Sci. 9:557-562.

Rose J.E., Amerault T.E. \& Rob T.O. 1974. Roles of conglutinin, complement and antibody size in the card agglutination test for bovine anaplasmosis. Am. J. Vet. Res. 35: 1147-115.

SAS Institute. 1982. SAS User's Guide: Statistics. Cary, USA. 584 p.

Schuntner C.A. \& Wright I.G. 1989. Detection of Babesia bigemina in cattle by a radioimmunoassay incorporating specifically depleted antigen. Vet. Parasitol. 31: 229-241.

Todorovic R.A. \& Kuttler K.L. 1974. A babesiosis card agglutination test. Am. J. Vet. Res. 35:1347-1350.

Todorovic R.A., Viscaino O.G. \& Adams L.G. 1976. The detection of babesial antibodies by the complement fixation technique. Revta Inst. Colomb. Agropec. 6: 213-233.

Wright I.G. 1990. Immunodiagnosis and immunoprophilaxis against hemoparasites Babesia sp. and Anaplasma sp. in domestic animals. Rev. Sci. Tech. Off. Int. Epizoot. 9:345-356. 